\title{
The honey-buzzard in Scotland: a rare, secretive and elusive summer visitor and breeder
}

\author{
C.J. McInerny ${ }^{1} \&$ K.D. Shaw ${ }^{2}$ \\ ${ }^{1} 10$ Athole Gardens, Glasgow G12 9AZ \\ E-mail: chris.mcinerny@glasgow.ac.uk \\ ${ }^{2} 13$ Chalmers Brae, Anstruther, Fife KY10 3BY \\ E-mail: kenshaw495@gmail.com
}

\begin{abstract}
The honey-buzzard (Pernis apivorus) is probably Scotland's most enigmatic breeding bird of prey. The raptor is extremely difficult to observe, being rare, secretive and elusive. Over the past few years we have discovered two populations of honey-buzzards in central Scotland. Systematic and intensive monitoring of these populations has revealed new information about the species' annual breeding cycle. In this paper we review the history and distribution of the honey-buzzard in Scotland and summarise the results of our recent studies in central Scotland, which have considerably increased understanding of the species.
\end{abstract}

\section{INTRODUCTION}

The honey-buzzard is widespread in the Western Palearctic, breeding from Britain and continental Europe through to western Asia (del Hoyo et al., 1994; Hagemeijer \& Blair, 1997; Batten, 2001; FergusonLees \& Christie, 2001). The raptor is a trans-equatorial migrant, spending the summer in the northern hemisphere to breed and wintering in sub-Saharan Africa (Vansteelant et al., 2017). It is largely a woodland species, nesting in trees and flying to more open habitats to find food items, mainly social wasps and bees (Hymenoptera), but also amphibians, reptiles and more rarely birds (Trap-Lind, 1962; Cobb, 1979; McInerny, 2014; Harwood \& Richman, 2016).

\section{HISTORY IN SCOTLAND \\ 19th century}

For as long as the honey-buzzard has been recorded in Scotland it has always been a rare summer visitor and occasional breeder (Thom, 1986; Forrester et al., 2007). The first dated record was mentioned for the Parish of Hamilton, South Lanarkshire in the New Statistical Account of Scotland (1845) with one "shot at Chatelherault in the autumn of 1831 " when the species had "not hitherto obtained a place in the Scottish Fauna". Breeding was first reported in Aberdeenshire at two sites: prior to 1840 at Abergeldie and at Ballogie in 1867 (MacGillivray, 1840, 1855; Gray, 1871; Sim, 1903).

\section{0th and 21st centuries}

The rare summer visitor and occasional breeding status in Scotland continued during the 20th century until the 1970s when systematic monitoring revealed that nesting occurred in the country every year, although with varying and usually small numbers (Harvey, 2005; Forrester et al., 2007). This trend follows observations elsewhere in the UK where originally it was a rare breeder only in southern England, but becoming more widespread in England and Wales since the 1990s (Roberts et al., 1999; Batten, 2001; Roberts \& Lewis, 2003; Brown \& Grice, 2005; Clements, 2005; Appleby, 2012).

In northern Scotland, a population was found in one area and studied from 1973 to 1986 , peaking at 13 occupied sites, with a further seven occupied sites in a second area (Harvey, 2005). Nesting also occurred near Inverness in 1976 and Moray and Nairn in 1977. By the early 1990s the total Scottish population was approximately 22 pairs, this including 15 pairs in northern Scotland with nesting in Ross and Cromarty, Inverness, Badenoch and Strathspey, and Moray and Nairn. In 1992, five successful nests were located further south and east. At this time nesting at two new locations further south in Perth and Kinross and in Dumfries and Galloway was confirmed. Later in the 1990 s, the number of breeding pairs detected in northern Scotland dropped to two or three. In 2000, a UK-wide survey indicated 14 pairs in Scotland, with four confirmed as breeding (Ogilvie, 2003). By 2004 there were up to 15 occupied sites in northern Scotland supporting 15-20 pairs. By extrapolation, the total Scottish population was estimated to be about 50 pairs in the early 21 st century (Forrester et al., 2007).

In central Scotland the honey-buzzard was first recorded in the early 19th century and only occasionally reported through the first half of the 20th century (Shaw et al., 2017). It was not until the late 1980s and early 1990s that it was appreciated that nesting occurred annually, with one or two pairs present. Subsequently, more directed surveying identified one population of up to five territories in east central Scotland with associated non-breeding birds, together constituting up to 16 adults and sub-adults which, in 2016, produced up to seven young (Shaw et al., 2017). Continued monitoring of this population during 2017 revealed an increase to nine 
territories holding a minimum of 30 birds including up to 18 breeders, at least five non-breeders and seven or eight juveniles (McInerny et al., 2018; McInerny \& Shaw, 2018). A second population in west central Scotland was identified during 2017, containing two or three territories and up to nine birds, including up to six breeders, two non-breeders and one juvenile (McInerny et al., 2018). Surveying elsewhere in central Scotland revealed the presence of up to five isolated territories in potential breeding habitat with nine different birds. Thus, during 2017, central Scotland contained up to 49 honey-buzzards and 17 territories, including up to 24 breeders, seven non-breeders, nine non-assigned birds and eight or nine juveniles.

\section{CURRENT STATUS IN SCOTLAND \\ Distribution in Scotland}

In the early 21 st century the honey-buzzard has a fragmented and localised distribution in Scotland. Although breeding pairs are restricted to the mainland, they are present across the country in north, central and southern regions. Typically pairs hold territories in isolation. But in two areas of central Scotland populations have formed, with in one area nine territories and the other two or three territories.

The locations of breeding sites in this paper are deliberately kept confidential to protect the birds from human disturbance and persecution. It is important to emphasise that the honey-buzzard is a Schedule 1 species, meaning that observations should not cause any disturbance and that without an appropriate licence issued by Scottish Natural Heritage (SNH, 2018) nests should not be searched for. The authors of this paper obtained a Schedule 1 licence to complete some of their survey work, the results of which are summarised here.

\section{The breeding season}

As a summer breeding visitor, honey-buzzards are present in Scotland from mid-May until mid-September. During this time birds display, establish territories, make nests, lay eggs and raise young. Non-breeders are also present which associate with breeding pairs and populations. A graphical representation of the numbers of honey-buzzards (males, females and juveniles) seen in two areas of central Scotland through the 2017 breeding season is shown in Fig. 1.

\section{Arrival times}

Honey-buzzards arrive in Scotland during the second half of May (Fig. 1), although earlier arrivals have been recorded. For example, in central Scotland during 2016, singles were seen at one site on 11th and 14th May, and two were observed elsewhere on 14th May (Shaw et al., 2017). Typically, males arrive first and establish territories with females following one to two weeks later.

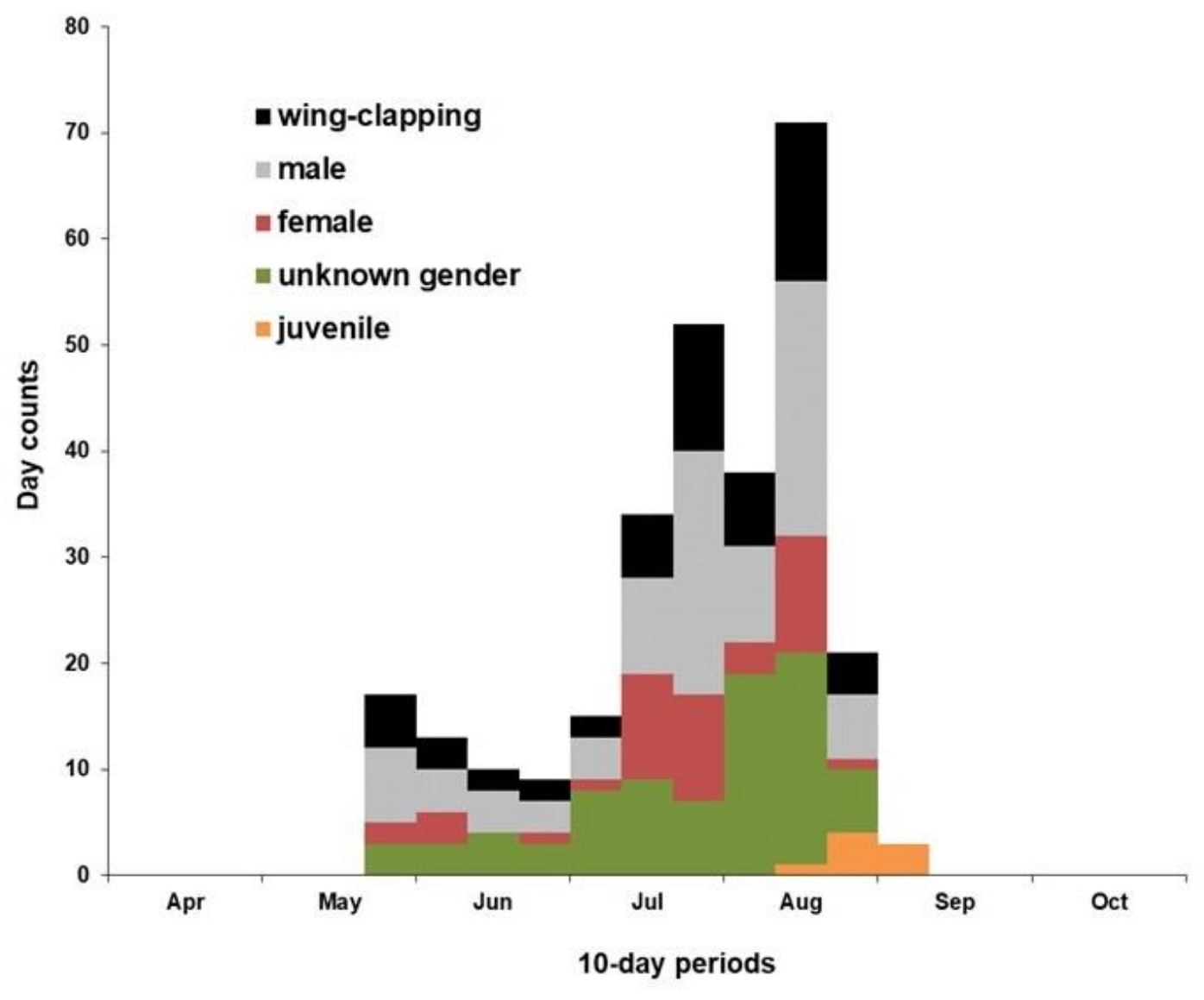

Fig. 1. Numbers of honey-buzzards (Pernis apivorus) in central Scotland during 2017. Up to 40 individuals in two populations were identified by plumage differences. The data show "day counts" (the cumulative daily counts of individual birds for each ten-day period from late May to early September), showing males, females, unsexed birds and juveniles separately, along with the wing-clapping 


\section{Display and territories}

On first arrival males display, establish territory, pair up, and nest usually close to the previous year's nest.

Honey-buzzards have an unusual and characteristic visual aerial display to establish and advertise territories (Roberts \& Law, 2014; Harwood \& Richman, 2016). Birds actively fly and soar above territorial areas, but during display they perform a wing-clapping butterflylike flight where the wings are temporarily raised above the body, almost touching, during which the wings quiver (Fig. 2). This movement lasts just two to three seconds before the wings are lowered and the bird flaps again to maintain flight. Such wing-clapping is often repeated, sometimes with over 100 consecutive displays. Both males and females can display, occasionally in response to each other, either low over woods or high in the sky. The wing-clapping can be performed at an extremely high altitude, with birds moving in and out of clouds.

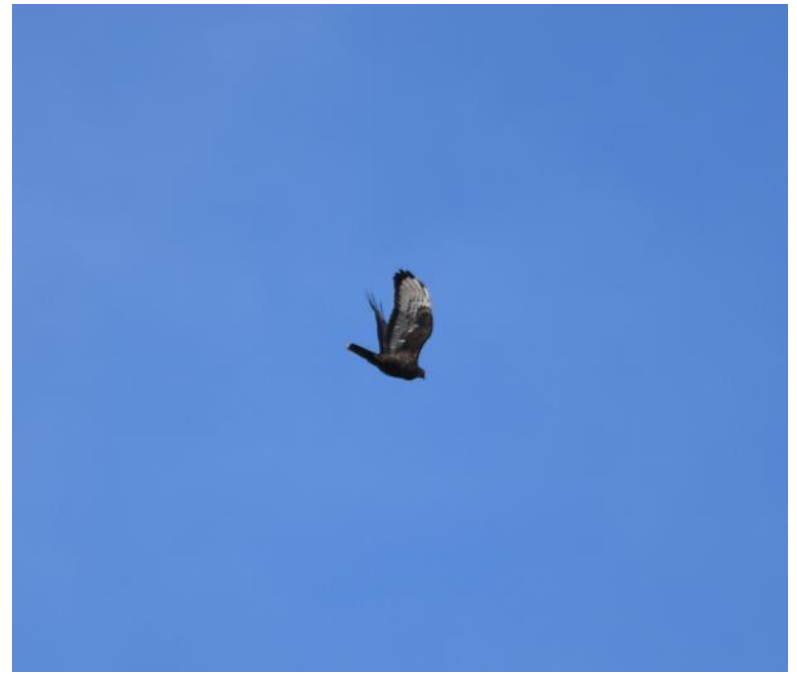

Fig. 2. Displaying male honey-buzzard (Pernis apivorus) in central Scotland, August 2017. (Photo: K. Hoey)

Studies have revealed that wing-clapping is mainly for territorial advertisement, rather than courtship between males and females (Roberts \& Law, 2014). Where birds are at low densities with isolated territories this results in little display at the beginning of the season. However, where birds are present at higher densities with adjacent and overlapping territories, males (and subsequently females) can be far more active at the start of season after arrival in May and early June with birds displaying, sometimes repeatedly (McInerny \& Shaw, 2018) (Fig. 1). Such increased display likely results from birds responding to other birds, in the same way the singing birds will often elicit singing from other nearby birds.

Protracted wing-clapping is more often observed later in the season during July and August (Fig. 1). Such display is mainly due to non-breeders (Roberts \& Law, 2014; Shaw et al., 2017; McInerny et al., 2018). Non-breeders display over territories in which they intend to nest in following years, with this often eliciting display from other non-breeding and breeding birds (McInerny, 2014).

Where populations of honey-buzzards form in optimum habitat, nests can be $2-3 \mathrm{~km}$ apart with overlap of territories (Voskamp, 2000; Hardey et al., 2013; Gamauf et al., 2013; Shaw et al., 2017; McInerny et al., 2018). This is unlike other woodland raptor species, such as northern goshawks (Accipiter gentilis), which manage more defined non-overlapping territories, whose perimeters they defend.

\section{Habitat and nests}

Honey-buzzards breed in a wide range of woodland habitats throughout the UK, from ancient broadleaf woodland, mixed broadleaf, to conifer and upland commercial conifer plantations (Roberts \& Lewis, 2003; Appleby, 2012; Hardey et al., 2013; Roberts \& Law, 2014; Harwood \& Richman, 2016).

In Scotland, birds nest in three habitat types: lowland areas of woodland and farmland; upland commercial conifer plantations; and areas of mixed broadleaf woodland and coniferous forest in the uplands (Forrester et al., 2007; SRSG, 2016). In central Scotland most honey-buzzards have been observed in the last habitat type, with fewer birds found in the two other habitats (Shaw et al., 2017; McInerny et al., 2018) (Fig. 3).

Nests are constructed on the branches of tall trees (Appleby, 2012; Hardey et al., 2013; Harwood \& Richman, 2016). Though nests are usually located in woods and plantations, they have also been found in smaller copses and even isolated trees (Clements, 2005).

In northern Scotland, $66 \%$ of nests were built in mixed broadleaf and coniferous forest (Forrester et al., 2007). In mixed broadleaf woodland, nests were found predominantly in beech (Fagus sylvatica) (55\%) and pedunculate oak (Quercus robur) (39\%), while in coniferous plantations Douglas fir (Pseudotsuga menziesii) (75\%) and Scots pine (Pinus sylvestris) (19\%) were preferred.

Diet

As suggested by their name, honey-buzzards consume social wasps and bees (Hymenoptera) as a major part of their diet (Trap-Lind, 1962; Cobb, 1979; Appleby, 2012; Harwood \& Richman, 2016). This includes both adults and grubs in combs, which birds will dig out of holes in the ground or trees. Honey-buzzards appear oblivious to the stings of these insects, apparently obtaining protection from their feathers (Sievwright \& Higuchi, 2016). 


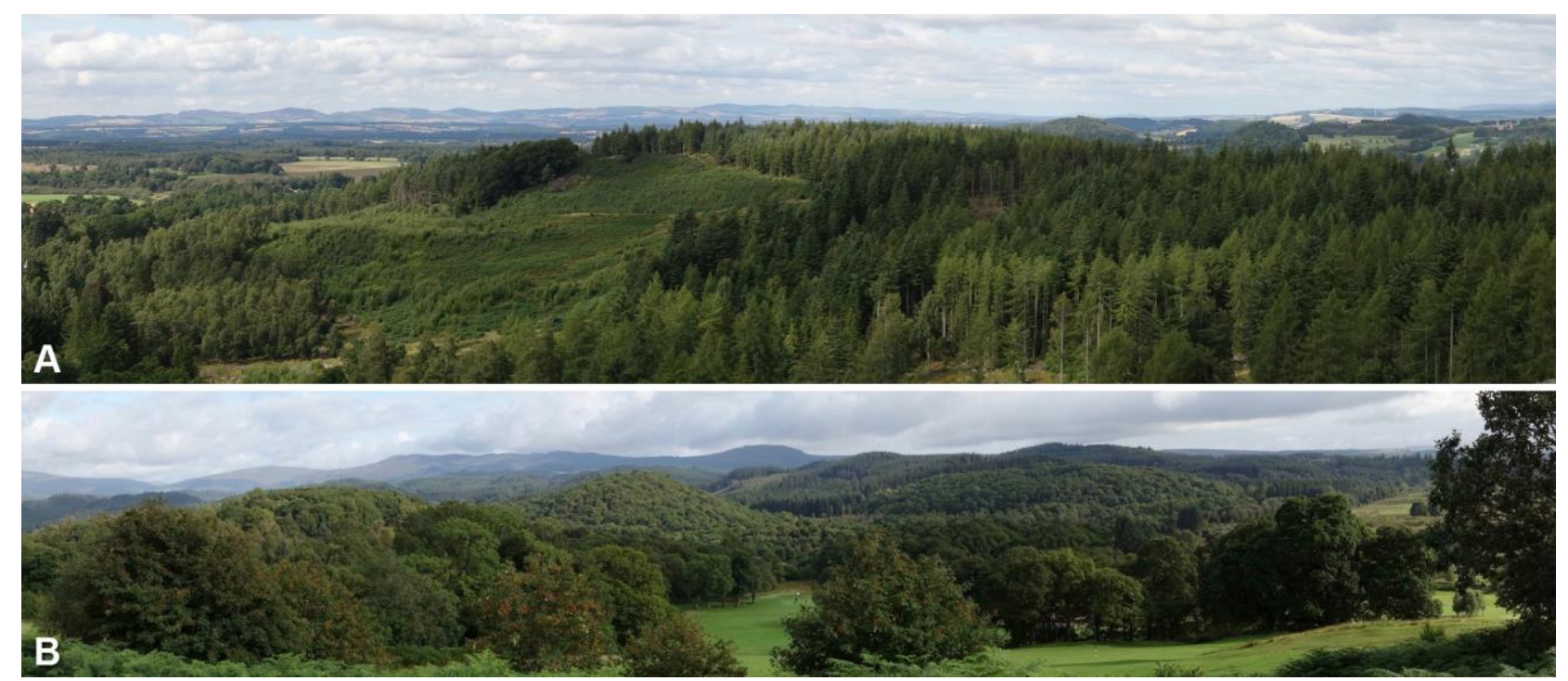

Fig. 3. Breeding habitat for honey-buzzards (Pernis apivorus) in east (A) and west (B) central Scotland. (Photos: C. McInerny)

Honey-buzzards also eat other food items when wasps and bees are not available. Common frogs (Rana temporaria) and frogspawn are often taken early in the season, with reptiles such as adders (Vipera berus), slow-worms (Anguis fragilis) and common lizards (Zootoca vivipara) also consumed (McInerny, 2014; McInerny et al., 2018). Nestling wood pigeons (Columba palumbus) and songbirds have been found in nests (Forrester et al., 2007).

\section{Egg-laying, incubation and young}

The average first egg-laying date for honey-buzzards in the UK is 2nd June (Roberts \& Law, 2014). Clutches of two or three eggs are incubated for around 32 days, hatching in late June or early July. However, occasionally in Scotland, breeding has occurred much later: at a nest in northern Scotland in 1991, a clutch was not laid until early July, four to five weeks later than usual (Forrester et al., 2007).

Birds become very inconspicuous during the incubation period, when pairs are especially secretive as a strategy to protect vulnerable young on nests (Fig. 1) (Roberts \& Law 2014).

In central Scotland juvenile honey-buzzards have been observed from 20th August to 6th September (Fig. 1), which is consistent with dates in England, where a range of 31st July to 7th September has been reported (Roberts \& Law, 2014), and from early August in other Scottish studies (Forrester et al., 2007).

\section{Breeding success}

During the period 1977-2004 breeding data were collected in northern Scotland from 11 locations (Forrester et al., 2007). Of 45 breeding attempts, 42 (93\%) were successful. The 79 fledged young resulted from seven broods with one chick, 33 broods of two, and two broods of three, giving a mean of 1.9 chicks/successful pair.
In central Scotland during 2016 seven juveniles were produced from five pairs, suggesting a breeding success of 1.4 chicks/successful pair (Shaw et al., 2017). In 2017, eight juveniles were produced from seven pairs, suggesting a breeding success of 1.1 chicks/successful pair (McInerny et al., 2018). Similar breeding success has been reported elsewhere in the UK (Roberts et al., 1999).

\section{Non-breeders}

Where honey-buzzards occupy adjacent multiple territories, non-breeding birds associate with breeding pairs. Honey-buzzards do not breed until they are two to three years old (Roberts, 2011; Roberts \& Law, 2014) and, although birds remain on the wintering grounds in Africa until they are two years old (Gamauf \& Friedl, 2011 ), over $50 \%$ of some breeding populations consist of non-breeders (Clements, 2005).

In central Scotland a number of non-breeders were identified (Shaw et al., 2017; McInerny et al., 2018). These were more visible than breeding birds, as they persistently flew around and between territories, sometimes displaying for up to an hour without pause, with over a hundred consecutive wing-claps. In comparison, breeding birds flew much less and displayed for a much shorter time, typically with only 15-20 wing-claps.

\section{Interactions with other birds of prey}

A number of other raptor species have been observed in Scotland that either breed within or otherwise use areas occupied by honey-buzzards, with some interactions noted (Shaw et al., 2017; McInerny et al., 2018).

In central Scotland raptors regularly seen in honeybuzzard territories include golden eagle (Aquila chrysaetos), osprey (Pandion haliaetus), red kite (Milvus milvus), common kestrel (Falco tinnunculus), peregrine ( $F$. peregrinus), northern goshawk, Eurasian sparrowhawk (A. nisus) and common buzzard (Buteo 
buteo). More rarely hen harrier (Circus cyaneus), Eurasian hobby ( $F$. subbuteo), merlin ( $F$. columbarius) and white-tailed eagle (Haliaeetus albicilla) have been recorded.

However, only four raptors have been observed to interact with honey-buzzards: common buzzard, northern goshawk, Eurasian hobby and osprey. The most frequent behaviour was interactions with common buzzards, sometimes flying together, but also with common buzzards aggressively chasing honeybuzzards. Honey-buzzards were also seen to soar and wing-clap with common buzzards a number of times. Northern goshawks, both juvenile males and juvenile females, were seen to interact and harass honeybuzzards on a number of occasions. More rarely hobbies were seen to fly with honey-buzzards. On two occasions interactions with an osprey were observed with birds flying together, and an osprey once harassing a honey-buzzard to which the honey-buzzard wingclapped in response.

\section{Departures}

Honey-buzzards depart from Scotland from late August, with adults leaving before juveniles (Fig. 1). Adults have been seen associating with juveniles, but have departed by the first week in September. Juveniles remain for a week or so after the adults with the last noted in central Scotland on 11th September 2016. These observations accord with studies elsewhere in the UK: in Yorkshire birds typically remain until 11th September, with an unusually late individual on 22nd September (Appleby, 2012).

The migration of honey-buzzards from Scotland to their African wintering grounds has been studied by satellitetracking, which has revealed much interesting information (Forrester et al., 2007). An adult which left breeding areas in Easter Ross on 5th September 2002 took a southerly route passing through England, western France and eastern Spain before crossing the Mediterranean, North Africa and the Sahara. It then passed through West Africa, finishing in coastal woodlands of Gabon on 28th October, a migration lasting almost two months. A tagged juvenile also followed this route, leaving in mid-September, though the transmitter failed in Morocco in late October. However, two other juveniles took a more wayward south-westerly course. One departed in late September and spent a month in Ireland before heading out into the Atlantic Ocean on 29th October when its radio stopped transmitting. Another departed in mid-September, only three weeks after fledging. It moved into the Atlantic Ocean having left south Wales on 23rd September. This young bird then flew non-stop for over four days and nights to travel about 5,000 $\mathrm{km}$ over the sea before finally perishing at sea $300 \mathrm{~km}$ from Madeira.

Similar migration strategies have been mapped by satellite-tracking of birds in continental Europe. These studies have shown that adult and juvenile honeybuzzards follow different routes during autumn migration, and that individuals change migration strategy during their lifetime (Hake et al., 2003; Vansteelant et al., 2017). Juveniles take longer to migrate, having shorter flights, and showed a larger directional scatter, with wind and geography postulated to influence their first migration south.

\section{Migrants}

As well as being a rare breeding species, the honeybuzzard is also a rare passage migrant, with birds from the Continent seen in Scotland on passage between their wintering and summering areas. Migrants are usually observed along the east coast and in Shetland and Orkney, both in spring and autumn. Honey-buzzards appear to cross water more readily than other raptor species (Agostini et al., 2015, 2016).

Larger numbers have been seen occasionally when meteorological conditions on the Continent have displaced migrating birds across the North Sea. For example in 2000 there was an exceptional autumn influx, with an estimated 1,879 in eastern and southern England between 20th September and 1st October (Fraser \& Rogers, 2002; Brown \& Grice, 2005). In the same period a smaller passage occurred in Scotland including 26 recorded between Shetland and the Borders, with birds west to Dumfries and Galloway.

\section{Wintering areas}

Honey-buzzards migrate to West Africa south of the Sahara where they spend the winter in rainforest habitat (del Hoyo et al., 1994; Ferguson-Lees \& Christie, 2001). Satellite-tracking has revealed that adults migrate directly to wintering sites where they remain within restricted territories (Strandberg et al., 2012). Conversely, immatures perform extensive movements within the tropics travelling large distances between wintering sites.

Immatures remain in wintering areas until they are two years old (Gamauf \& Friedl, 2011), and migrate north to breed when they are three years or older (Roberts, 2011; Roberts \& Law, 2014).

\section{Scottish population numbers and trends}

The numbers of honey-buzzards in Scotland appear to be increasing, although trends may be obscured as, being very secretive, the species is likely to be underrecorded. Furthermore, the numbers detected are also influenced by observer effort, which has fluctuated over the years.

In central Scotland the most recent population estimate for 2017 suggested up to 49 birds and 17 territories, including up to 24 breeders, seven non-breeders, nine non-assigned birds and eight or nine juveniles (McInerny et al., 2018). These numbers are an increase from 2016 when 23 birds were recorded, including 16 breeders and non-breeders and seven juveniles (Shaw et $a l ., 2017)$. In years previous to 2016 even fewer were detected, despite similar observer effort, so it is possible that numbers are increasing, at least in central Scotland. 
Such changes may reflect similar increases in breeding numbers and expansion of ranges both in England (Appleby, 2012; Harwood \& Richman, 2016) and Wales (Roberts et al., 1999). However, on the near Continent in north-west Europe populations have been experiencing declines (Bijlsma et al., 2012). These observations suggest that the recent increases in Scotland are more likely to be due to birds colonising from the expanding UK populations, rather than from Europe.

Honey-buzzards also breed in other regions of northern and southern Scotland, with these likely to contain a further 10-20 pairs. Thus the total Scottish population in 2017 may be in the range of 30-50 pairs, similar to that suggested for the early 21 st century when the national population was estimated to be 50 pairs (Forrester et al., 2007).

\section{FUTURE PROSPECTS}

The recent apparent increase in the central Scotland populations is encouraging for the species' prospects in Scotland. We plan to continue surveying the two populations to see if this trend continues, but also to discover more about these fascinating raptors. Future research will involve locating nests and monitoring productivity. We also wish to survey other potentially suitable habitat in central Scotland as it possible that the honey-buzzard is present elsewhere but undetected due to its rarity, and secretive and elusive nature.

\section{ACKNOWLEDGEMENTS}

We thank Kris Gibb, Rick Goater, Keith Hoey, Bruce Kerr, Ali Little, Kenny Little, John Nadin and numerous other co-workers who have collaborated with us to study honey-buzzards in central Scotland. We thank Keith Hoey for permission to use the photograph shown in Fig. 2. To support the fieldwork CJMcI received a travel grant from the Glasgow Natural History Society, Professor Blodwen Lloyd Binns Bequest; and KDS received a travel grant from the Scottish Ornithologists' Club. We thank an anonymous reviewer for improvements to the text.

\section{REFERENCES}

Agostini, N., Gustin, M., von Hardenberg, J. \& Panuccio, M. (2016). Wind patterns affect migration flyways and flock size of a soaring bird over sea. Avian Biology Research 9, 159-166. https://doi.org/10.3184/175815516X146279284481 05

Agostini, N., Panuccio, M. \& Pasquaretta, C. (2015). Morphology, flight performance, and water crossing tendencies of Afro-Palearctic raptors during migration. Current Zoology 61, 951-958. https://doi.org/10.1093/czoolo/61.6.951

Appleby, R. (2012). European Honey-buzzards Pernis apivorus in North Yorkshire: A Breeding History on a Learning Curve, 1895-2010. Privately published.

Batten, L.A. (2001). European honey-buzzard survey 2000 and 2001: preliminary results and request for further surveys. British Birds 94, 143-144.

Bijlsma, R.G., Vermeulen, M., Hemerik, L. \& Klok, C.
(2012). Demography of European honey buzzards Pernis apivorus. Ardea 100, 163-177. https://doi.org/10.5253/078.100.0208

Brown, A. \& Grice, P. (2005). Birds in England. T. \& A.D. Poyser, London.

Clements, R. (2005). Honey-buzzards in Britain. British Birds 98, 153-155.

Cobb, F.K. (1979). Honey buzzard at a wasps' nest. British Birds 72, 59-64.

del Hoyo, J., Elliott, A. \& Sargatal, J. (1994). Handbook of the Birds of the World. Volume 2. Lynx Edicions, Barcelona, Spain.

Ferguson-Lees, J. \& Christie, D.A. (2001). Raptors of the World. Christopher Helm, London.

Forrester, R.W., Andrews I.J., McInerny, C.J., Murray, R.D., McGowan, R.Y., Zonfrillo, B., Betts, M.W., Jardine, D.C. \& Grundy, D.S. (Editors) (2007). The Birds of Scotland. The Scottish Ornithologists' Club, Aberlady.

Fraser, P.A. \& Rogers, M.J. (2002). Report on scarce migrant birds in Britain in 2000. British Birds 95, 606-630.

Gamauf, A. \& Friedl, C. (2011). Zug- und Überwinterungsstrategien junger

Wespenbussard Pernis apivorus [Migration and wintering strategies of young honey-buzzards Pernis apivorus]. Vogelwarte 49, 290-291.

Gamauf, A., Tebb, G. \& Nemeth, E. (2013). Honey buzzard Pernis apivorus nest-site selection in relation to habitat and the distribution of goshawks Accipiter gentilis. Ibis 155, 258-270. https://doi.org/10.1111/ibi.12023

Gray, R. (1871). Birds of the West of Scotland, including the Outer Hebrides. Thomas Murray \& Son, Glasgow.

Hagemeijer, W.J.M. \& Blair, M.J. (Editors) (1997). The EBCC Atlas of European Breeding Birds: their Distribution and Abundance. T. \& A.D. Poyser, London.

Hake, M., Kjellén, N. \& Alerstam, T. (2003). Agedependent migration strategy in honey buzzards Pernis apivorus tracked by satellite. Oikos 103, 385396. https://doi.org/10.1034/j.1600-0706.2003.12145.x

Hardey, J., Crick, H., Wernham, C., Riley, H., Etheridge, B. \& Thompson, D. (2013). Raptors: a Field Guide for Surveys and Monitoring. Third Edition. The Stationery Office (TSO), Scotland.

Harvey, M. (2005). Honey-buzzards in Britain. British Birds 98, 489-490.

Harwood, J. \& Richman, P. (2016). Honey-buzzards in the North Yorkshire Moors National Park. https://1drv.ms/b/s!AueMdnxhrcZdfAR1_TfLj3AR D2c

Macgillivray, W. (1840). A History of British Birds. Volume 3. Scott, Webster \& Geary, London.

Macgillivray, W. (1855). The Natural History of Deeside and Braemar. Privately published, London. https://doi.org/10.5962/bhl.title.106835

McInerny, C.J. (2014). Honey-buzzard carrying a reptile during display flight. Scottish Birds 34, 41.

McInerny, C.J. \& Shaw, K.D. (2018). Observations on the 'wing-clapping' aerial display of honey-buzzards 
in central Scotland. British Birds 111, 226-227.

McInerny, C.J., Shaw, K.D., Little, A., Little, K., Hoey, K., Gibb, K. \& Kerr, B. (2018). Honey-buzzards in central Scotland: observations and comparisons from two study areas during 2017. Scottish Birds 38, 15-29.

New Statistical Account of Scotland. (1845). Parish of Hamilton, County of Lanark, Volume 6, 260. http://stataccscot.edina.ac.uk/static/statacc/dist/hom e

http://stataccscot.edina.ac.uk/static/statacc/dist/view er/nsa-vol6-

Parish_record_for_Hamilton_in_the_county_of_La nark_in_volume_6_of_account_2/

Ogilvie, M.A. (2003). European honey-buzzards in the UK - correction to breeding totals. British Birds 96, 145.

Roberts, S. (2011). Honey buzzards in Wales 2011. Boda Wennol 2011, 12-13.

Roberts, S.J. \& Law, C. (2014). Honey-buzzards in Britain. British Birds 107, 668-691.

Roberts, S.J. \& Lewis, J.M.S. (2003). Observations of European honey-buzzard breeding density in Britain. British Birds 96, 37-39.

Roberts, S.J., Lewis, J.M.S. \& Williams, I.T. (1999). Breeding European honey-buzzards in Britain. British Birds 92, 326-345.

Scottish Natural Heritage (SNH). (2018). https://www.nature.scot/professionaladvice/safeguarding-protected-areas-andspecies/protected-species/protected-species-zguide/protected-species-birds

Scottish Raptor Study Group (SRSG). (2016). http://scottishraptorstudygroup.org

Shaw, K.D., McInerny, C.J., Little, A., Little, K., Nadin, J.S. \& Goater, R. (2017). An exceptional season at a central Scotland honey-buzzard study area. Scottish Birds 37, 3-13.

Sievwright, H. \& Higuchi, H. (2016). The feather structure of Oriental honey buzzards (Pernis ptilorhynchus) and other hawk species in relation to their foraging behavior. Zoological Science 33, 295302. https://doi.org/10.2108/zs150175

Sim, G. (1903). The Vertebrate Fauna of 'Dee'. Wyllie, Aberdeen.

Strandberg, R., Hake, M., Klaassen, R.H.G. \& Alerstam, T. (2012). Movements of immature European honey buzzards Pernis apivorus in tropical Africa. Ardea 100, 157-162. https://doi.org/10.5253/078.100.0207

Thom, V.M. (1986). Birds in Scotland. T. \& A.D. Poyser for SOC, Calton.

Trap-Lind, I. (1962). Observations on a honey buzzard digging out a wasps' nest. British Birds 55, 36.

Vansteelant, W.M.G., Kekkonen, J. \& Byholm, P. (2017). Wind conditions and geography shape the first outbound migration of juvenile honey buzzards and their distribution across sub-Saharan Africa. Proceedings of the Royal Society B 284, 20170387. https://doi.org/10.1098/rspb.2017.0387

Voskamp, P. (2000). Population biology and landscape use of the honey buzzard Pernis apivorus in Salland. Limosa 73, 67-76. 